\title{
nature
}

13 March 2003 Volume 422 Issue no 6928

\section{Time to unite Islam and science}

Science in Muslim countries is weak. The reasons for this deserve attention, as do the consequences for these nations' economic health. A meeting last week provided a start in this direction.

66 am a Muslim, and we Muslims don't usually speak out on such matters. But I'm going to, as I have a responsibility towards our children, society, education and the advancement of scientific thinking." The seemingly taboo question that Çigdem Kagitcibasi, a psychologist and member of the Turkish Academy of Sciences, was nervously addressing was whether a lack of democracy and freedom of expression in the Islamic world might be one reason why there is no substantial culture of science and technology in these countries.

Addressing a satellite workshop on 'science, religion and values' at a meeting of top science officials from Islamic and Western countries last week in Trieste, Italy (see page 101), Kagitcibasi argued the need to tackle head-on this question: "Is 'Muslim culture' helping the advancement of our society or not?"

Provocatively, and perhaps undiplomatically given her secular Turkish background, she questioned, for example, Saudi Arabia's sponsorship of Wahhabism, a particularly rigid and austere form of Islam, at mosques and madrassas, or Islamic religious schools, worldwide. "Why are they opening up religious schools everywhere instead of ordinary schools devoted to basic education?" she asked.

Mohamed Falougi, deputy director general of the Islamic Educational, Scientific and Cultural Organization, protested that such discussion was "inappropriate" and that Kagitcibasi had no right to say such things: "Islamic countries can teach any way they want, just as Judaism or Christianity do." It is true that explanations for the scientific ills in Islamic countries are complex. But the time has come to scrutinize Islam's relationship, inhibitory or otherwise, with science.
Neglecting the impact of Islam on science would not only be blind, but a disservice to Muslim peoples, who, if they are to become prosperous, need to shift from their flagging natural resource- and agriculture-based economies to knowledge-based ones. The Islamic world's science spending is just $0.2 \%$ of gross national product, its population of scientists is meagre, and its legal framework for innovation largely non-existent. Some countries, such as Pakistan, have recently shifted towards a culture of technology and scientific knowledge, but this is an exception. Its visionary, the higher-education minister, Atta-urRahman, is an outspoken proponent of the need for a revolution in the Islamic world's commitment to science and education.

The Koran encourages the pursuit of science, and in its heyday the Islamic world was a cradle of science for six centuries. But many scientists, including Rahman, think that aspects of contemporary Muslim cultures are hindering the emergence of scientific cultures through narrow-mindedness, lack of basic freedoms, and pressure on individuals to conform, and not to challenge or think critically and creatively. Greater dialogue is needed among Muslim scholars and scientists about how to encourage science to flourish in the Islamic world.

Poverty, unemployment, the Middle East crisis and a perception of injustice with respect to the actions of the West are creating a cycle of violence and hatred, which often finds its expression in radical Islam. Science and education, the freedom to think critically, and contact with Western scientists can help to educate both sides, leading to a reform of Islam that brings to the fore the tolerance and scholarship that was for centuries the mark of the religion's practice.

\section{A little protectionism goes a long way}

China's stalling on introducing transgenic crops may frustrate outsiders, but helps it nurture its own biotechnology industry.

$\mathrm{t}$ is highly unusual for a developing country to assume a leading position in an important field of scientific endeavour. But China says that it intends to do just that in agricultural biotechnology and all the signs are that its plan should be taken seriously.

China has already devoted a considerable research effort to plant science, including the development of transgenic crops (see page 111). Its public programme is making progress on many fronts, from sequencing the rice genome to producing hundreds of promising crop varieties. The programme is characterized not just by the nation's customary determination, but also by talent, imagination and a strong outward orientation that engages Chinese scientists in collaboration with colleagues overseas.

Amid all this activity, Chinese regulators have recently been reluctant to approve the commercial planting of transgenic food crops (genetically modified cotton is already well established). The government claims to be worried about whether Europe will accept exports of transgenic food, and about public reaction at home. Neither argument is convincing: its agricultural trade with Europe is small, and the public reaction is firmly under the state's control.

What China really wants is some breathing space to enable its own transgenic technology to catch up with that abroad. There's nothing inherently wrong with this: unless the United States wants to fight a war to open up China's markets, as Britain once did to force it to accept opium imports, it needs to recognize China's strategic need to develop its own agricultural biotechnology. Advocates of US agricultural biotechnology, such as Senator Chuck Grassley (Republican, Iowa), probably want the United States to take China to the World Trade Organization for protecting its markets in this way. But this heavy-handed approach will do the technology no favours.

Like all developing countries, China needs time to assess and develop agricultural biotechnology on its own terms. The stranglehold on patents for methods and genes that Western corporations and universities have obtained in this arena is already making life hard for agricultural scientists across the developing world. At least China has the political and financial clout to overcome these obstacles and develop the technology in the interests of its own farmers.

An old Chinese proverb says that if you sit on the banks of the river long enough, the bodies of your enemies will float down past you. It is not clear if the author had President Bush, Senator Grassley or the board of Monsanto in mind. But China's patience will, in the long run, be the best way to assure the fruitful introduction of agricultural biotechnology into the world's most populous nation. 